\title{
Juniperus L. for Restoration of Degraded Forest Lands in Turkey
}

\author{
Cengiz Yücedağ ${ }^{1}$, Sezgin Ayan²*, Perla Farhat ${ }^{3}$, Halil Barış Özel ${ }^{4}$
}

(1) Burdur Mehmet Akif Ersoy University, Faculty of Engineering Architecture, Department of Landscape Architecture, TR-15030 Istiklal Campus, Burdur, Turkey; (2) Kastamonu University, Faculty of Forestry, Silviculture Department, Kuzeykent Campus, TR-37100 Kuzeykent Campus, Kastamonu, Turkey; (3) Université Saint-Joseph, Faculté des Sciences, Laboratoire Biodiversité et Génomique Fonctionnelle, Campus Sciences et Technologies, Mar Roukos, Mkalles, BP: 1514 Riad el Solh, Beirut 1107 2050, Lebanon; (4) Bartın University, Faculty of Forestry, Silviculture Department, TR-74100 Bartın, Turkey

* Correspondence: e-mail: sezginayan@gmail.com
Citation: Yücedağ C, Ayan S, Farhat P, Özel HB, 2021. Juniperus L. for Rehabilitation of Degraded Forest Lands in Turkey. South-east Eur for 12(1): 71-81. https:// doi.org/10.15177/seefor.21-01.

Received: 31 Oct 2020; Revised: 31 Dec 2020; Accepted: 5 Jan 2021; Published online: 4 Feb 2021

\begin{abstract}
Degraded forests are among of the most important environmental and commercial problems around the world. Turkey has 22.74 million hectares of forest area, out of which 9.656 million ha (42\%) are unproductive. To transform these unproductive forests into productive ones, forest restoration including rehabilitation is one of the best actions. In this sense, juniper species play an important role for degraded lands because they are drought-tolerant and withstand aridity and poor soils better than most timber species grown in Turkey. Therefore, this review presents the ecological considerations for the restoration of degraded forest lands in Turkey under the conditions of climate change. Within this framework, it focuses on the production of planting stock of juniper species, the significance of site-species matching, and post-planting site maintenance for successful rehabilitation.
\end{abstract}

Keywords: degraded land; juniper; planting stock, rehabilitation; Turkey

\section{INTRODUCTION}

Degraded forests have lost much of their productivity, biodiversity and most of the ecological goods and services that they once provided (Lamb and Gilmour 2003). Forest degradation has on-site and off-site ecological and environmental effects, including the deterioration of agroecological conditions, increased flooding, lower water quality and the siltation of dams. Unfortunately, human activities are one of the major causes of forest degradation (Mantang et al. 2003). Therefore, the rehabilitation of these lands needs more than just a biological perspective and sustainable management (Thang 1987, Mantang et al. 2003). Rehabilitation is the action of redirecting the existing ecosystem composition or structure towards a more desired state (Burton and Macdonald 2011). In the process of rehabilitation, the conservation of plant diversity and ecosystems both in situ and ex situ, and rehabilitation of degraded lands is ecologically significant (Soejono et al. 2013).

Turkey is located in three biogeographical regions: Anatolian, Mediterranean and the Black Sea region. Owing to its location, it consists of various ecosystems, including forests, mountains, steppe, wetlands, coastal and marine ecosystems (IUCN 2012). Therefore, it is an important hotspot of biodiversity and endemism. However, overgrazing, overcutting, fires, clearance for agriculture, wars and general misuse of the land have contributed to the drastic decrease in forest area. According to the report of Turkish Ministry of Forest and Water Affairs in 2019, Turkey has 22.74 million ha of forest land of which $42 \%$ (9.656 million ha) are degraded (OGM 2019a). In Turkey, Juniperus L. is considered as one of the most important genus of Turkish conifer forests. Despite the fact that species of this genus cover a large area of ca. $958.423 \mathrm{ha}$, most of that area is actually unproductive and degraded (TOD 2019).

Juniperus, locally known as "Ardıç", represents the most diverse genus inside Cupressaceae family and the second most diverse within conifers with approximately 75 species and 40 intraspecific taxa (Farjon 2010, Romo et al. 2013, Adams 2014). Junipers grow in a large spectrum of habitats from the sea level to the highest mountains (Adams 2014). In Turkey, they are considered as the most resistant tree species to extreme growing conditions and are 
the last to move away from the area in which is subjected to deforestation (OGM 2006). Indeed, its ability to adapt to harsh environmental conditions makes juniper a resistant and robust tree in the face of winter frost, water stress, rocky slopes and shallow soils (Gauquelin et al. 1988, Rawat and Everson 2012, Mathaux et al. 2016, Evren and Kaya 2020). Recently, it was proved that species from this genus are capable to regulate stomatal transpiration for a better water management during drought season (Abdallah et al. 2020), and that their tolerance to summer drought increases with the age (Rozas et al. 2009). All those remarkable characteristics make Juniperus an essential potential genus for reforestation and ecological rehabilitation particularly in areas with harsh environment where they are probably the only species able to grow and develop (Yücedağ et al. 2010, Çetin 2014). This includes the Mediterranean basin, where the impact of the recent climatic change is severe and characterized by an increase in the temperature and a decrease in precipitation (Houghton et al. 1996). Based on their resistance characteristics, junipers were chosen as the keystone species for many reforestation and rehabilitation activities such as in Balochistan province of Pakistan (Sarangzai et al. 2012), in Lebanon (MoE 2009), Greece (Vrahnakis et al. 2017), and India (Rawat and Everson 2012).

Juniperus is a species-rich genus represented in Turkey with 8 taxa belonging to the Caryocedrus, Juniperus, and Sabina sections (Eliçin 1977, Adams 2014): J. communis L., J. excelsa M. Bieb., J. foetidissima Willd., J. oxycedrus L., J. phoenicea L., J. deltoides R.P. Adams (Adams and Mataraci 2011), J. sabina L., and J. drupacea Lab. (Anşin and Özkan 1993, Davis 2001). Juniper forests in Turkey are dominated by J. excelsa (ca. $82 \%$ ), followed by J. foetidissima (ca. 15\%) and J. phoenicea (ca. 3\%) (OGM 2006; Figure 1). However, these forests are subjected to a severe degradation accompanied with the general decline of forests, which makes rehabilitation efforts a crucial priority.
This paper presents a review of the ecological features to use junipers for the rehabilitation of degraded forest lands. Even though several forest tree species are relevant in rehabilitation activities, this article focuses on species belonging to Juniperus, which is one of the dominant genera in Turkey both ecologically and economically. Specifically, it focuses on the production of planting stock of juniper species, the significance of site-species matching, and postplanting site maintenance for successful rehabilitation.

\section{JUNIPER LAND DEGRADATION}

Human interference played a major role in juniper lands' degradations. Juniper species are highly appreciated in many industrial and medical productions (Adams 2014). For decades, juniper species have been used to produce medicines due to their anti-microbial and antifungal properties (Asili et al. 2010, Orhan et al. 2012, Hojjati et al. 2019, Vasilijevic et al. 2019, Zivic et al. 2019). As well, some species were found to be potentially important for cancer treatments (Sadeghi-Aliabadi et al. 2009, Kapdan et al. 2019). Moreover, juniper trees were intensively cut for the use of their strong wood for furniture and boat production (Adams 2014). Juniper wood was preferred more than other species' wood for the production of outdoor furniture due to its effective, beautiful and distinctive scent (Şirin and Topay 2019).

There are several ecological reasons for juniper forest degradation and fragmentation. Juniper species are windpollinated, produce small pollen grains at low quantity and pollen grains have a slow setting velocity (Douaihy et al. 2012), which affects the pollination process. Plus, juniper trees have a low density of reproductive adults, they have a low sound seed ratio (Yücedağ et al. 2010) and suffer from several germination obstacles (Gültekin 2007, Yücedağ et al.

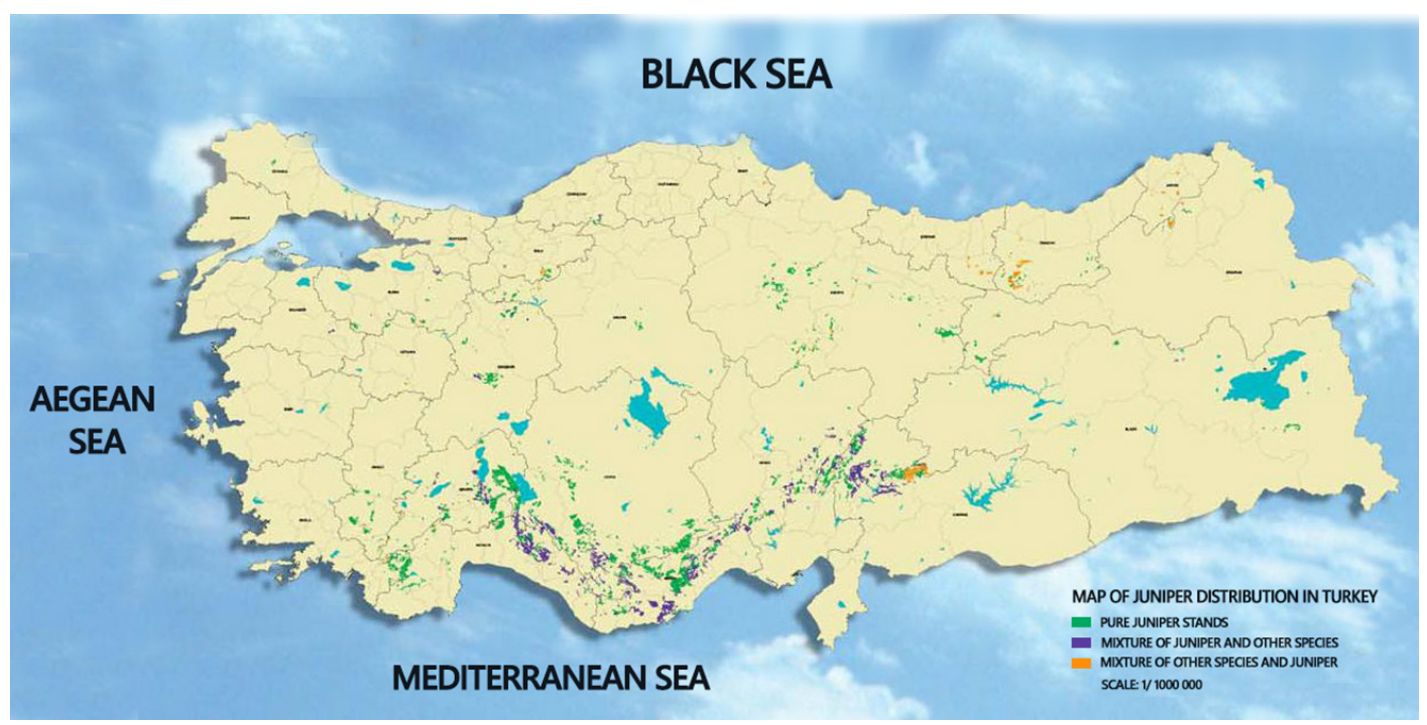

Figure 1. Juniperus geographical distribution in Turkey (extracted from TrAgLor 2018). 
2010), which reduce the resilience of juniper forest, leading to their fragmentation.

Additionally, climate change has presented dramatic consequences to plant species and their ecosystems (Allen et al. 2010). The increase of temperatures and the reduction of precipitation, especially in arid and semi-arid environments, induced by climate change showed an increase in drought stress on juniper trees at all altitudes (Seim et al. 2016). Despite that Juniperus is drought-resistant, the fast climate change would induce a dramatic decline in their population sizes as noted in Oman populations for J. seravschanica (MacLaren 2016).

To summarize, the main factors of degradation and fragmentation of juniper forests in Turkey are the historical and recent human activities, the extreme environmental conditions in the distribution area of juniper species, the difficulty of natural regeneration and the impact of rapid climate change of the recent years.

\section{CHALLENGES TO LARGE-SCALE PRODUCTION OF JUNIPER PLANTING STOCK}

\section{Seed Supply}

The reproductive ecology of juniper provided considerable challenges for the forest nurseries, which may explain, in part, the low rehabilitation and afforestation practices in the past. Seed production in junipers is unpredictable because junipers have a low sound seed ratio (Yücedağ et al. 2010). The number of sound seeds per cone can be determined by the cutting method before collecting cones (Yücedağ et al. 2010). Total juniper seed production per year from all Turkish juniper populations from 2012 to 2019 is available in Figure 2, showing a big variation throughout the years (minimum $=1107 \mathrm{~kg}$, maximum $=5929 \mathrm{~kg}$ ). This variation in seed production depends on the population location where seeds are collected (Gültekin and Gültekin 2007).

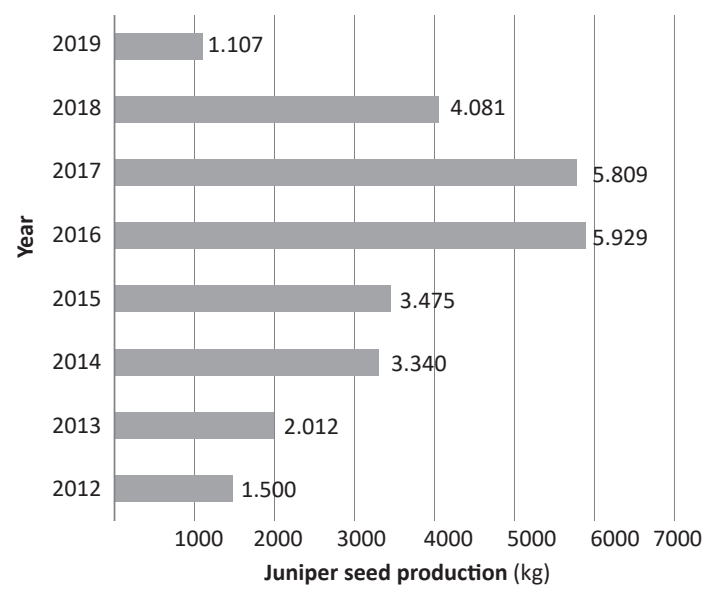

Figure 2. Juniper seed production by year in Turkey (OGM 2019b).
Ideally, in heavy seed years, the mean of sound seed ratio was found to be around $30-52 \%$ (Gültekin 2007). However, this percentage could be affected by the method used in the estimation, which was in this case, the "area detection $x$ tree selection" method. Also, this estimation could be affected by the condition of the sampled female cones. Therefore, coarse, healthy (not infected by insects), large and bright female cones should be collected (if available) (Gültekin 2007, Yücedağ et al. 2010).

\section{Propagation by Seed}

Juniper seeds have various germination obstacles. Different methods and their combinations are used for removing these obstacles (Gültekin and Gültekin 2003, Gültekin 2007, Yücedağ et al. 2010, Gezer and Yücedağ 2013). The propagation success depends on the species and the method used. In Turkish nurseries, J. foetidissima and other native juniper species' seeds are sown after stratification from March to May or directly sown from August to September in natural conditions. If the obtained seeds are immediately sown or stratified, then no pretreatment is applied. The earlier the juniper seeds were sown, the more success in germination rate was obtained. Generally, seeds are sown in late spring for J. foetidissima and in summer or early fall for other juniper species (Gültekin 2007).

In the case of seeds pretreatment, after obtaining juniper seeds from cones, they are floated in various concentrations of $\mathrm{NaCl}$ solutions depending on the species (e.g. 25000 ppm for J. excelsa). This step aims to detect sound seeds (unfloated seeds) and therefore remove other floated empty seeds. Before sowing, seeds are kept in water containing $20 \%$ wood ash for 15 days to remove resin and oils from seeds. After this process, seeds are desiccated under shady conditions for a couple of days (Gültekin et al. 2003, Gültekin 2007, Yücedağ 2008, Yücedağ et al. 2010).

In harsh semi-arid restoration lands in Turkey, the production of containerized seedlings for juniper plantings should be a priority according to the results of the recent scientific research (Örtel et al. 2020, Yücedağ et al. 2021). In the production of containerized juniper seedlings, the ideal growing medium is a mixture of $50-60 \%$ forest soil, $5-10 \%$ fine sand and 30-40\% humus (Gültekin 2007). Gülcü et al. (2010) also reported that $J$. excelsa seedlings with the best quality in terms of the seedling height and root collar diameter were grown in $11 \mathrm{~cm} \times 30 \mathrm{~cm}$ pots, using a growing medium mixture that contains $70 \%$ forest soil, $15 \%$ humus, and $15 \%$ pumice or creek sand. Besides, Gülcü and Gültekin (2005a) stated that seed provenance was very important in the production of $J$. excelsa seedlings. Two methods are used for sowing seeds in containers. First, six seeds are directly sown in each container. Second, the germinated seeds after stratification are sown. In terms of nursery practice, the use of the second method is shown to be both cost-effective and easy, especially for J. foetidissima. On the other hand, transplanting to the container should be done in winter or early spring, but no later than this period (Gültekin 2007).

In the production of bare root seedlings, seeds are usually sown in late spring, summer and fall, depending on the juniper species. The optimal sowing depth is $5 \mathrm{~mm}$ for $J$. excelsa (Gülcü and Gültekin 2005b), $6 \mathrm{~mm}$ for J. oxycedrus and 
J. phoenicea, and 10 to $15 \mathrm{~mm}$ for J. foetidissima. Seed sowing and mulching were applied to seedbeds. Also, covering seed sowing parcels with plastic shader was found useful in frosty days of late fall and winter. It has been noticed that around 30 to $50 \mathrm{~g}$ seeds of J. excelsa, J. oxycedrus and J. phoenicea and ca. 80 to $160 \mathrm{~g}$ seeds of $J$. foetidissima are required to obtain 200 to 350 seedlings per $\mathrm{m}^{2}$ (Gültekin 2007).

In the growing season, junipers grow roots before shoots. Thus, weeding should be applied 3 to 4 times in three weeks' intervals until June. It is usually done by hand or by machines during the period of the first three months. Hoeing is done twice in May and June in the seedbeds without mulching. The roots are pruned by traction-drawn blades, cutting them at $25 \mathrm{~cm}$ below ground level, at the beginning of September. It is not possible to use $2+0$ years-old bare root seedlings for restoration activities due to the excess of stem/root ratio. For this reason, two root pruning at $25 \mathrm{~cm}$ below ground level in March and July of the second year are proper for this kind of seedlings. In the production of bare-root seedlings, green manure application must be applied to the sowing parcels (Gültekin 2007).

During and after the germination process, measures should be taken for seeds and seedling protection from several stressors. Birds are considered an important problem for juniper seeds. For this reason, the best method is to put "telis" or synthetic material directly onto seedbeds. As well for seedlings, birds along with other animal species such as rabbits, rodents, cockchafers and soil worms can cause a dramatic loss in the increment of young juniper seedlings in a short time. Besides, fungal diseases present a moderate to low problem as they are rarely seen in juniper seedling propagation (Gültekin 2007). Additionally, apart from biotic stressors, juniper seedlings are very sensitive to the abiotic conditions and especially to late frost. It has been previously reported that junipers are affected by low temperatures during germination (Gültekin 2007). For this reason, planting under a canopy or a nurse plant could be advantageous by flattening the environmental stresses on the young seedlings. This was proved by Khoshnevis et al. (2019), who showed that canopy and its geographic orientation had significant positive effects on J. excelsa seed germination and seedling survival rates.

Natural juniper seed sources from gene conservation forests are available in Turkey and are registered in the National Register System. These seed stand and gene conservation forests are listed in Table 1. According to this list, four seed stands and 16 gene conservation forests in Turkey were selected and registered (OGM 2020).

The total (815.5 ha) seed stand area consists of J. excelsa (3 pcs - 457 ha) and one J. phoenicea (1 pcs - 353.5 ha). In addition, the total (2992.1 ha) gene conservation forest area consists of $J$. drupacea (one pcs - 15.1 ha), J. excelsa (11 pcs - 2451.3 ha), J. foetidissima (three pcs - 369.4 ha) and J. oxycedrus (one pcs - 156.3 ha) (OGM 2020).

Table 1. Seed sources according to different juniper species in Turkey (Edited as of 3 January 2020).

\begin{tabular}{|c|c|c|c|c|c|c|c|}
\hline $\begin{array}{l}\text { National } \\
\text { Registered } \\
\text { Number }\end{array}$ & Source* & Species & $\begin{array}{l}\text { Regional } \\
\text { Directorate }\end{array}$ & $\begin{array}{c}\text { Forest } \\
\text { Enterprise } \\
\text { Directorate }\end{array}$ & $\begin{array}{l}\text { District } \\
\text { Chief }\end{array}$ & Compartment Number & $\begin{array}{l}\text { Area } \\
\text { (ha) }\end{array}$ \\
\hline 375 & SS & J. excelsa & ANKARA & BEYPAZARI & KARACA & 373,490 & 149.6 \\
\hline 378 & SS & J. excelsa & ANKARA & ESKIPAZAR & EMIROGLU & 2,3 & 207.9 \\
\hline 377 & SS & J. phoenicea & MUGLA & MILAS & GURCAMLAR & $253,254,255,256$ & 358.5 \\
\hline 392 & SS & J. excelsa & ISPARTA & EGIRDIR & EGIRDIR & 29,50 & 99.5 \\
\hline 12 & GCF & J. excelsa & MERSIN & TARSUS & BULADAN & $52,53,54$ & 163 \\
\hline 13 & GCF & J. oxycedrus & MERSIN & MERSIN & KIZILBAG & $140,141,143$ & 156.3 \\
\hline 17 & GCF & J. excelsa & MERSIN & MUT & SERTAVUL & 145,146 & 223.4 \\
\hline 19 & GCF & J. foetidissima & DENIZLI & ACIPAYAM & $\mathrm{ALCl}$ & 49,64 & 75.5 \\
\hline 22 & GCF & J. excelsa & DENIZLI & ACIPAYAM & $\mathrm{ALCl}$ & 79,80 & 132.2 \\
\hline 32 & GCF & J. excelsa & MUGLA & SEYDIKEMER & SEKI & 147,176 & 133.4 \\
\hline 39 & GCF & J. excelsa & DENIZLI & ESKERE & YELKENCIDAG & 52,53 & 117.6 \\
\hline 40 & GCF & J. excelsa & KONYA & KONYA & HADIM & $143,144,145,146$ & 530.7 \\
\hline 93 & GCF & J.excelsa & ANTALYA & SERIK & OREN & $1,2,3,6$ & 232.3 \\
\hline 112 & GCF & J. foetwidissima & ISPARTA & BUCAK & KESTEL & 126 & 97.5 \\
\hline 120 & GCF & J. foetidissima & ISPARTA & GOLHISAR & DIRMIL & $139,140,141$ & 196.4 \\
\hline 124 & GCF & J. excelsa & KONYA & BEYSEHIR & BEYŞEHIR & $1005,1006,1007,1008$ & 269.5 \\
\hline 190 & GCF & J. excelsa & ESKIŞEHIR & ESKIŞEHIR & SEYITGAZI & 132,168 & 252 \\
\hline 195 & GCF & J. excelsa & ESKIŞEHIR & MIHALICCIK & BEŞPINAR & $229,230,233,234$ & 235.7 \\
\hline 308 & GCF & J. excelsa & ANKARA & BEYPAZARI & BEYPAZARI & 701,705 & 161.5 \\
\hline 273 & GCF & J. drupacea & K.MARAŞ & ANDIRIN & ÇATAK & 157 & 15.1 \\
\hline
\end{tabular}

SS: Seed stand; GCF: Gene Conservation Forest 
According to the statements by the Minister of Agriculture and Forestry of Turkey (OGM 2019b), a total of 25 million juniper seedlings were produced between 2011 and 2018. However, Farahat (2020) investigated J. phoenicea populations in North Sinai Mountains in Egypt and reported that the seedling supply of juniper species was extremely restricted. According to the statements mentioned above, it has been concluded that juniper seedling propagation is a challenging practice that depends on many factors such as year, population, country and species.

\section{Vegetative Propagation}

Although there are important constraints on the seed supply of junipers, the use of vegetative propagation should not be an indispensable option. Vegetative propagation is highly useful for species where seed germination was limited or in case of the failure of optimal germination protocols. In particular, vegetative propagation is an alternative for juniper species presenting low seed germination rates and for those who produce empty seeds at high frequency. Vegetative growing capacities of junipers are very high during the first several years (Gültekin 2007). In Turkey, vegetative propagation of junipers has remained experimental (Keskin 1989, Ayan et al. 2004). For instance, Tektaş et al. (2017) reported that the most proper hormone concentration was identified to be $5000 \mathrm{ppm}$ naphthalene acetic acid (NAA) and the most proper planting time was identified to be April for reliable rooting of J. excelsa. However, these factors could not be generalized on the genus scale and they depend largely on the species of interest (Haile et al. 2011, RamosPalacios et al. 2012). Among many case studies where this technique was used for restoration purposes, we mention the propagation of native species (Buddleja cordata HBK, Dodonaea viscosa Jacq and Senecio praecox D.C) in Mexico potentially utilized for reforestation (Ramos-Palacios et. al. 2012), the propagation of the native silver fir and Taxus $L$. for the conservation of the Apennine beech forests (Amiata 2007) and the propagation of several tropical trees (Zahawi and Holl 2014). However, vegetative propagation is a difficult and time-consuming practice (Haile et al. 2011) which is coupled with a major disadvantage regarding the offspring genetic diversity (Thomas et al. 2014). This technique will produce clones having the same genetic material as the parental plants. Therefore, the genetic diversity of the propagated trees will be reduced, which might have a severe negative effect on the population and its ability to adapt to biotic and abiotic stresses, especially in degraded land (Thomas et al. 2014). Based on these disadvantages, we highly recommend avoiding vegetative propagation for rehabilitation practices. However, if it is the only possible propagation technique, it should be elaborated by taking cuttings from as many individual plants as possible (Marzo et al. 2015).

\section{Mycorrhizae}

A lot of attention has been paid to the great effect of mycorrhizal symbioses in restored ecosystems and serious efforts have been done on establishing the efficiency of the plant-mycorrhizae relationship (Chen et al. 2014). Before application on the field, three important criteria must be fulfilled. First, a compatible mycorrhiza to the plant species of interest must be chosen, second, the mycorrhizal fungus must be suitable to the site to be rehabilitated and finally, no difficulties in the inoculum production must be present (Rincon et al. 2001). For some juniper species, Cenococcum Moug. \& Fr., fungi are successfully used (Chen et al. 2014). However, this issue was not well explored neither in Turkey nor for Juniperus. Therefore, further work must be elaborated to discover the specific mycorrhizal fungus for Turkish Juniperus species and the one which is suitable for the sites to be restored. Mycorrhizae inoculation should be conducted for the rehabilitation of the degraded lands having extreme climate conditions in Turkey. If bare root seedlings are used for rehabilitation activities, mycorrhizae inoculation should be conducted both for seedlings in the nursery and planting pit in the rehabilitation area. Besides, the inoculation is sufficient only at the nursery stage if seedlings were grown in containers (OGM 2006). These treatments will provide better growth and survival rate in the early stages of planting. However, there is still a clear gap of knowledge on the extent to which inocula are adapted to some host species and site conditions.

\section{Seeds' Genetic Constraints}

The genetic quality of juniper's seed has not been yet well studied. Thus, to make some generalizations we are still relying on recent studies of gene flow and genetic diversity of adult juniper populations (Korshikov and Nikolaeva 2007, Yücedağ 2008, Hojjati et al. 2009, Yücedağ et al. 2010, Douaihy et al. 2011, Gülsoy et al. 2012, Korshikov and Nikolaeva 2013, Yücedağ and Gailing 2013a, 2013b, Pinna et al. 2014, Saeed et al. 2017, Yücedağ and Ozel 2017, Mazur et al. 2018). Studies have shown that a reduction in stand density and isolation of individuals may enhance inbreeding. Douaihy et al. (2011) stated that losses of the old juniper individuals and the lack of natural regeneration could result in a negative genetic effect represented by the fragmentation of local population diversity. Therefore, ideally, seed collections should be made from primary forest stands with a good density of reproductive adults. Unfortunately, due to the extent of forest degradation, this may not always be an option.

\section{REHABILITATION STATUS IN TURKEY}

Rehabilitation practices officially began in 1998 in Turkey and were conducted on about 3.1 million hectares totally in 2019 (OGM 2019a). These practices have essential benefits for the sustainability of natural resources such as soil and water. In addition, rehabilitation works have a role in sustaining both Turkey's and the world's biodiversity and in providing several ecosystem services such as carbon storage.

Recently, the importance of the usage of native species during rehabilitation has been highlighted in many practices worldwide (Lamb et al. 2005) and in Turkey. This practice provides significant environmental benefits such as the conservation of the species and its genetic diversity, the reduction of the risk of invasiveness, the high survival 
rate of native species during rehabilitation actions due to their adaptation to the local climate (Bozzano et al. 2014). Using native and local species in Turkey for rehabilitation has recently increased. Indeed, to restore degraded land in Artvin-Turkey, three native species (J. foetidissima, Punica granatum L., and Cotinus coggygria Scop.) were used and they revealed high survival rates (greater than $70 \%$ ) over a period of two years (Balaban 2011). In addition, for the restoration activities of Burdur-Turkey, six native and drought-resistant species were suggested: J. oxycedrus, J. excelsa, Quercus libani G. Olivier, Pinus brutia Tenore, Cedrus libani A. Rich., and P. nigra J.F. Arnold (Şahin et al. 2014). These findings emphasize the importance of research to enable site-species matching for the restoration of degraded forest, and the great potential for native species to be used for establishing a nurse canopy. Studies exploring the levels of local adaptation in junipers will not only improve our ability for site-species matching, but also the extent to which generalizations can be made across regions.

In Turkey, juniper forests cover an area of 958.423 ha, of which 218.300 ha $(22.77 \%)$ is productive, and 740.123 ha $(77.22 \%)$ is unproductive. Some statistics about juniper forests are presented in Table 2 (TOD 2019).

The natural regeneration of juniper trees is very low, which implicates conservation and rehabilitation actions. Open juniper forests (10 to $40 \%$ crown density) and the surrounding degraded areas should be considered for rehabilitation activities. Usually, habitats where junipers grow are characterized by extreme environmental factors (e.g., drought, low nutrient and high/low temperatures), which makes rehabilitation activities more challenging. Therefore, a combination and novel forest establishment methods might be considered during rehabilitation. In all cases, the rehabilitation of an area should be planned according to the land characteristics. Also, planting methods are adapted to the land as an example; methods will differ between areas with or without deep soil (OGM 2006).

It should be noted that four-years-old saplings obtained from natural regeneration have the same height as one-yearold saplings grown in nurseries and used in afforestation. Therefore, planting saplings from nurseries in most cases is cost-effective and planted seedlings grow tall more quickly. Especially, planting $1+1$ or $2+0$ containerized saplings is essential for a rapid increase in height. Thus, completion and maintenance costs are minimized. In some harshly arid areas, deeper tillage, irrigation and fertilization in the first years would be beneficial. Sexual regeneration methods should be used in rocky areas where tillage is not possible.
On the other hand, the number of juniper seedlings planted per hectare in the rehabilitation of degraded lands should be twice as much as the rainfall amount of the region (OGM 2006).

Sapling counts should be conducted for at least two years and $70 \%$ success should be considered sufficient. In dense rocky areas, this ratio can be reduced to $50-60 \%$ (OGM 2006). Research conducted in the rehabilitation area of Senirkent-Isparta district, Turkey, showed that about $60 \%$ of juniper saplings survive (Sungur and Bilir 2015). Another study (Yücedağ et al. 2021) exploring the variability in growth, photosynthetic pigments, proline and plant nutrients of seven J. excelsa populations grown in Davraz mountain of Isparta, Turkey (Figure 3) revealed that the mean height and diameter of 10-years-old saplings found were $94.47 \mathrm{~cm}$ and $4.18 \mathrm{~mm}$, respectively. Also, the same study reported that very few saplings had a damaged crown, but the survival rate of all populations was $100 \%$. Gültekin et al. (2005) stated that the survival rates in the Lakes District of Turkey, where one-year-old bare-root J. excelsa and J. foetidissima saplings are planted, were $73 \%$ and $92 \%$, respectively. Another research assessing the rehabilitation works in Burdur, Turkey, reported that the mean height of 8 -years-old J. excelsa saplings ranged from 80 to $151 \mathrm{~cm}$ and its growing in the same area was better than that of Cedrus libani (Çetin 2014). Another study investigating the effects of four different seedling types (1+0 and 2+0 aged bareroot seedlings, $1+0$ and $1+1$ aged containerized saplings) of $J$. excelsa on survival rate and their growth in YalvaçIsparta and Elmalı-Antalya districts of Turkey showed that sapling type significantly affected survival rate, and 1+1 and $1+0$ aged containerized saplings were the most successful seedling types (Örtel et al. 2020).

J. excelsa and J. foetidissima saplings are highly used for rehabilitation practices in Turkey. However, there is no exact statistical data on how much each juniper species is produced or planted in this region.

Rehabilitation of degraded forest lands is mostly via the planting of juniper seedlings rather than seed sowing. Thus, this management strategy fundamentally depends on the ability to produce sufficient numbers of viable seedlings of juniper species for planting. However, seed sowing is a mandatory method especially in rocky areas (Gültekin 2007). It can be applied in two ways. First, stratified seeds in summer and fall are sown in natural areas. The second method, direct seed sowing without stratification, can be used in the winter season. Patch sowing should be used particularly in rocky areas and at least 6 seeds should be sown in each

Table 2. The area, volume and increment status of juniper forests in Turkey (TOD 2019).

\begin{tabular}{|c|c|c|c|}
\hline Attribute & Productive forest area & Unproductive forest area & Total \\
\hline Area (ha) & 218,300 & 740,123 & 958,423 \\
\hline Volume $\left(\mathrm{m}^{3}\right)$ & $15,238,806$ & $4,827,863$ & $20,066,669$ \\
\hline Volume in unit area $\left(\mathrm{m}^{3} \cdot \mathrm{ha}^{-1}\right)$ & 69.81 & 6.52 & 20.94 \\
\hline Annual increment $\left(\mathrm{m}^{3} \cdot\right.$ year $\left.^{-1}\right)$ & 331,079 & 93,740 & 418,623 \\
\hline Annual increment in unit area $\left(\mathrm{m}^{3} \cdot \mathrm{ha}^{-1} \cdot \mathrm{year}^{-1}\right)$ & 1.52 & 0.13 & 0.44 \\
\hline
\end{tabular}




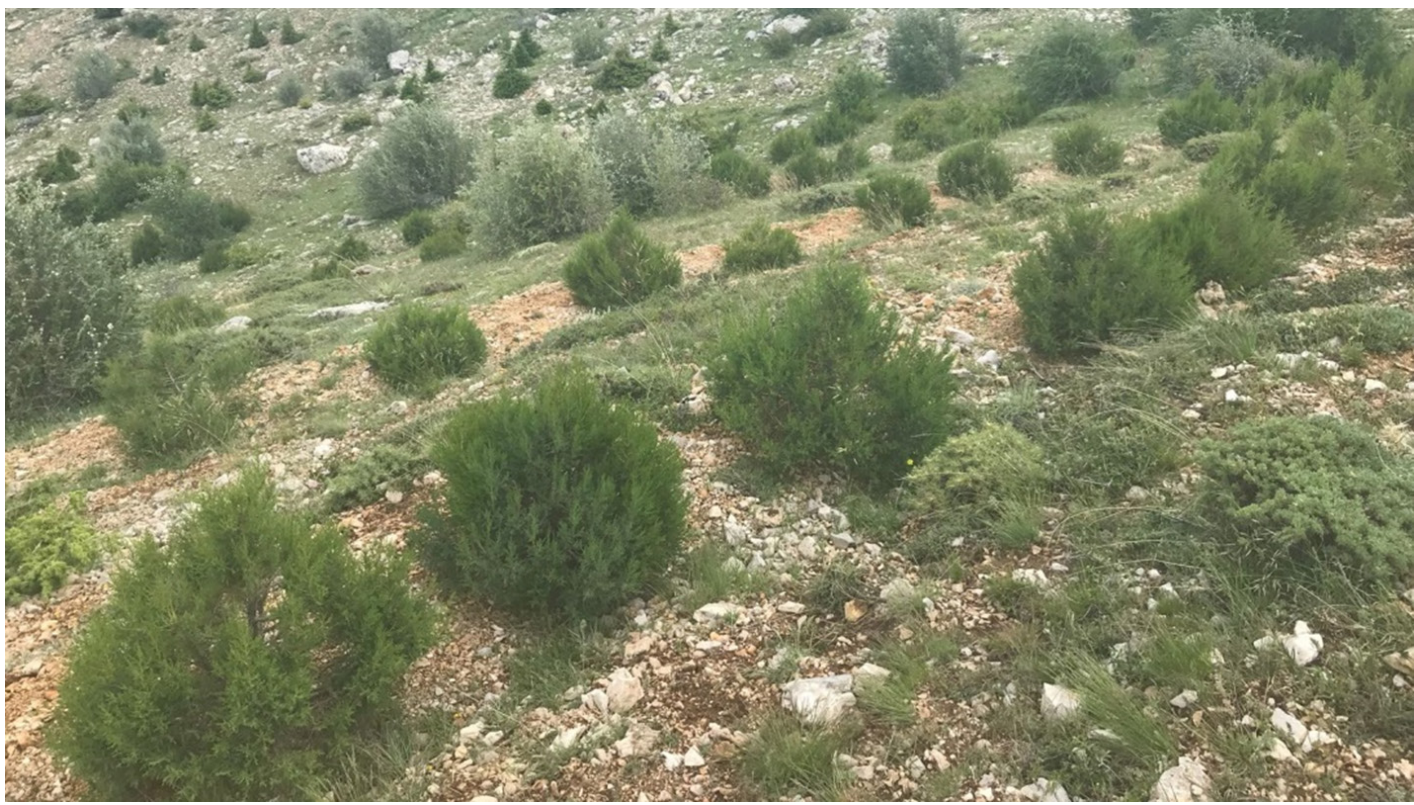

Figure 3. Ten-year-old plants in Davraz Common Garden, Isparta of Turkey (Yücedağ et al. 2021).

patch. Previous experimental designs showed that with direct seed sowing, the germination of J. foetidissima seeds occurred in the second year, while there was no germination in the first year. Germination rates of J. excelsa, J. oxycedrus and $J$. phoenicea were found to be about $15-60 \%$ in the first year and the germination of the remaining seeds took place in the second and third year. It has been recommended, in order to have a successful germination rate in nature, that at least $4 \mathrm{~kg}$ of sound seeds of $J$. excelsa, $5 \mathrm{~kg}$ of sound seeds of J. oxycedrus and J. phoenicea, and $20 \mathrm{~kg}$ of sound seeds of J. foetidissima per hectare should be sown. In the case of extreme sites, it was recommended to sow two folds of the quantities of seeds mentioned above (Gültekin 2007; Gültekin and Gültekin 2007).

Unfortunately, the sown seeds suffer from rabbits, sheep and goats during germination. Fall and winter should be preferred for seed sowing. If possible, it should be done in the late summer or fall following the first rains. Seed sowing in the spring should be avoided. Young seedlings that survive till the end of the first year in the harsh lands are usually permanent on site (Gültekin 2007).

\section{EVOLUTIONARY CHALLENGE FOR LAND REHABI- LITATION BY JUNIPERUS}

Recently, Juniperus was found to be an exception within conifers regarding the evolutionary phenomenon, polyploidy (Farhat et al. 2019a, b). Polyploidy or whole genome duplication is when an organism possesses more than two complete sets of chromosomes (Comai 2005). For example, a triploid, tetraploid and hexaploid hold three, four and six sets of chromosomes, respectively. Polyploidy is considered to be a major phenomenon for plant evolution and especially for angiosperms (Chen 2007, Soltis and Soltis 2009, Tayalé and Parisod 2013). Indeed, around 50 to $80 \%$ of angiosperm taxa are polyploid and it was estimated that all angiosperms had at least one polyploidization event in their ancestry (Van de Peer et al. 2017, Otto and Whitton 2000). However, polyploidy was found to be very rare within gymnosperms (ca. 5\%) and especially within conifers (ca. $1.5 \%$ ) where polyploid cases were mainly found to be tetraploid except in one species, Sequoia sempervirens (D.Don) Endl., the only hexaploid (Khoshoo 1959, Ahuja 2005, Scott et al. 2016). Recently, Juniperus showed a relatively high rate of polyploidy with ca. $15 \%$ of tetraploid and one hexaploid, J. foetidissima (Farhat et al. 2019a), which makes this genus an exception within conifers regarding this phenomenon. Moreover, intraspecific variations in the ploidy levels were detected in some juniper taxa, J. sabina, and J. chinensis L., where some populations were found as diploid and the others as tetraploid (SiljakYakovlev et al. 2010, Farhat et al. 2019a). Therefore, the ploidy level of juniper seedlings selected for rehabilitation may present an additional challenge to rehabilitated population. Indeed, in the long term, the evolution of the species used during the rehabilitation action would be affected by the choice of individuals and their ploidy levels. Also, this choice would affect the future of the restored region and its neighborhood because polyploidy affects the geographical distribution of the species (Weiss-Schneeweiss et al. 2013). Indeed, polyploidy would affect positively or negatively the polyploid taxa distribution by affecting their adaptation to environmental factors (Weiss-Schneeweiss et al. 2013). Also, in some cases, polyploid plants would become invasive due to their high environmental adaptation 
followed by the genetic variations acquired by polyploidy (Te Beest et al. 2012). Recently, Farhat et al. (2020) found that interspecific hybridization occurred between diploid and tetraploid Juniperus taxa present in sympatry in the wild. Therefore, while using more than one juniper species in the rehabilitation action, a historical assessment on juniper taxa that might be present in the same location is highly recommended. We also suggest that the source of the germplasm used for rehabilitation is from the juniper trees of the degraded population before its degradation. This will ensure planting of the same ploidy level as the previously destroyed juniper population. Alternatively, we suggest to take germplasm from the nearest population and to check their ploidy levels.

\section{POST-PLANTING SITE MAINTENANCE}

In general, a $70 \%$ survival rate for juniper afforestation areas is considered sufficient and successful. Unless these areas have big gaps, replanting of dead saplings should not be made. If necessary, the containerized seedlings based on the characteristics of the field should be replanted at the end of the first year. Usually, there is no weed problem in the first year in most of the fields prepared by machine. Hoeing is done in the period when cracks occur in the soil and it is repeated if necessary according to the climatic conditions. Generally, there is no need to hoe after the second year in juniper afforestation areas. In extremely arid areas, deep tillage, irrigation and fertilization in the first year would be beneficial. In areas where weeds present a problem, they should be removed and their residues should be spread out on the same area (OGM 2006, Gültekin and Gültekin 2007).

The main goal in the maintenance of junipers' rehabilitation areas is to overcome the first vegetation period. Indeed, deaths from drought are very low after this period. If rabbits and other domestic animals are not allowed to enter the juniper rehabilitation areas, the saplings will survive. Nevertheless, to ensure the rehabilitation success, the areas should be observed for at least 2 years and maintenance should not be ignored. The technical staff of the district where the rehabilitation activity was conducted must program their maintenance work in terms of period and activities (Gültekin and Gültekin 2007).

\section{CONCLUSION}

The advancement of strategies for rehabilitation of degraded forest lands is globally of leading importance. These rehabilitation works which require great political driving force and considerable economic incentives can improve the biodiversity and economic value of Turkey's lands, providing socio-economic benefits as well as environmental awareness. Establishment of ex-situ conservation units and seed orchards of juniper species are required. Increasing both our knowledge and capacity to produce genetically diverse planting stock from the species' range is crucial for successful forest recovery. All these efforts could result in significant ecological and economic benefits for Turkish forestry.

\section{Author Contributions}

$\mathrm{CY}, \mathrm{SA}, \mathrm{PF}$, and $\mathrm{HBO}$ conceived, designed, and wrote the paper together.

\section{Funding}

This research received no external funding.

\section{Conflicts of Interest}

The authors declare no conflict of interest.

\section{REFERENCES}

Abdallah MAB, Durfee N, Mata-Gonzalez R, Ochoa CG, Noller JS, 2020. Water Use and Soil Moisture Relationships on Western Juniper Trees at Different Growth Stages. Water 12(6): 1596. https://doi.org/10.3390/w12061596.

Adams RP, 2014. Junipers of the World: The genus Juniperus. $4^{\text {th }}$ ed. Trafford Publishing, Bloomington, Indiana, USA, 422 p.

Adams RP, Mataraci T, 2011. Taxonomy of Juniperus deltoides forma yaltirikiana in Turkey: Leaf terpenoids and SNPs from nrDNA and petN. Phytologia 93: 293-303.

Ahuja MR, 2005. Polyploidy in Gymnosperms: Revisited. Silvae Genet 54(2): 59-69.

Allen CD, Macalady AK, Chenchouni H, Bachelet D, McDowell N, Vennetier M, et al. 2010. A Global Overview of Drought and Heat-Induced Tree Mortality Reveals Emerging Climate Change Risks for Forests. Forest Ecol Manag 259(4): 660-84. https://doi. org/10.1016/i.foreco.2009.09.001.

Amiata M, 2007. TUCAP-Conservation of Apennine Beech Forests with Abies alba SIC Pigelleto. Available online: https://ec.europa.eu/ environment/life/project/Projects/index.cfm?fuseaction=search. dspPage\&n proj id=2644 (20 October 2020).
Anşin R, Özkan C, 1993. Tohumlu Bitkiler (Spermatophyta). Black Sea Technical University, Faculty of Forestry, Trabzon, Turkey, 167/19.

Asili J, Emami SA, Rahimizadeh M, Fazly-Bazzaz BS, Hassanzadeh MK, 2010. Chemical and Antimicrobial Studies of Juniperus sabina L. and Juniperus foetidissima Willd. Essential Oils. J Essent Oil Bear PI 13(1): 25-36. https://doi.org/10.1080/0972060X.2010.10643787.

Ayan S, Küçük M, Ulu F, Gerçek V, Şahin A, Sıvacıoğlu A, 2004. Vegetative Propagation Possibilities of Some Natural Juniper (Juniperus L.) Species. Gazi Üniversitesi Orman Fakültesi Dergisi 4(1): 1-12.

Balaban IY, 2011. An Investigation on Success of Afforestation Study Using Some Drought Tolerant Species in Artvin Region. MSc Thesis, University of Artvin Çoruh, Artvin, Turkey.

Bozzano M, Jalonen R, Thomas E, Boshier D, Gallo L, Cavers S, Bordács S, Smith P, Loo J, 2014. Genetic Considerations in Ecosystem Restoration Using Native Tree Species. State of the World's Forest Genetic Resources - Thematic Study. FAO and Bioversity International, Rome, Italy.

Burton PJ, Macdonald SE, 2011. The Restorative Imperative: Challenges, Objectives and Approaches to Restoring Naturalness in Forests. Silva Fennica 45(5): 843-863. 
Çetin M, 2014. Burdur Çevresi Ağaçlandırma ve Erozyon Kontrolü Çalışmalarının Değerlendirilmesi. T.C. Orman ve Su İşleri Bakanlığı Çölleşme ve Erozyonla Mücadele Genel Müdürlüğü, Ankara, Turkey, $83 \mathrm{p}$.

Chen YL, Liu RJ, Bi YL, Feng G, 2014. Use of Mycorrhizal Fungi for Forest Plantations and Minesite Rehabilitation. In: Solaiman Z, Abbott L, Varma A.(eds) Mycorrhizal Fungi: Use in Sustainable Agriculture and Land Restoration. Soil Biology, vol 41. Springer, Berlin, Heidelberg, Germany, pp. 325-355. https://doi.org/10.1007/9783-662-45370-4 21.

Chen ZJ, 2007. Genetic and Epigenetic Mechanisms for Gene Expression and Phenotypic Variation in Plant Polyploids. Annu Rev Plant Biol 58: 377-406. https://doi.org/10.1146/annurev. arplant.58.032806.103835

Comai L, 2005. The Advantages and Disadvantages of Being Polyploid. Nat Rev Genet 6(11): 836-846. https://doi.org/10.1038/nrg1711.

Davis P, 2001. Flora of Turkey. Edinburgh University Press, 11: 8-10.

Douaihy B, Vendramin GG, Boratyński A, Machon N, Dagher-Kharrat $M B, 2011$. High Genetic Diversity with Moderate Differentiation in Juniperus excelsa from Lebanon and the Eastern Mediterranean Region. AoB Plants 2011: 1-14. https://doi.org/10.1093/aobpla/ plr003.

Douaihy B, Sobierajska K, Jasinńka AK, Boratyńska K, Ok T, Romo A, Machon A, Didukh Y, Bou Dagher-Kharrat M, Boratyński A, 2012. Morphological Versus Molecular Markers to Describe Variability in Juniperus excelsa subsp. excelsa (Cupressaceae). AoB Plants 2012: 1-14. https://doi.org/10.1093/aobpla/pls013.

Eliçin G, 1977. Türkiye'de doğal ardıç (Juniperus L.) taksonlarının yayılışları ile önemli morfolojik ve anatomik özellikleri üzerine araştırmalar. İstanbul Üniversitesi Orman Fak. Yayın 232: 109-121.

Evren ÖH, Kaya N, 2020. A Comparison of Some Physical and Chemical Soil Characteristics of Crimean Juniper (Juniperus excelsa M. Bieb) Populations in Turkey. Journal of Tekirdag Agricultural Faculty 17(1): 37-52. https://doi.org/10.33462/jotaf.556666.

Farahat EA, 2020. Age Structure and Static Life Tables of the Endangered Juniperus phoenicea L. in North Sinai Mountains, Egypt: Implication for Conservation. J Mt Sci 17: 2170-2178. https://doi.org/10.1007/s11629-020-6123-2.

Farhat P, Hidalgo O, Robert T, Siljak-Yakovlev S, Leitch I, Adams RP, Bou Dagher Kharrat M, 2019a. Polyploidy in the Conifer Genus Juniperus: An Unexpectedly High Rate. Front Plant Sci 10:676. https://doi.org/10.3389/pls.2019.00676.

Farhat P, Siljak-Yakovlev S, Adams RP, Bou Dagher Kharrat M, Robert T, 2019b. Genome Size Variation Aand Polyploidy in the Geographical Range of Juniperus sabina L. (Cupressaceae). Bot Lett 166(2): 134143. https://doi.org/10.1080/23818107.2019.1613262.

Farhat P, Takvorian N, Avramidou M, Garraud L, Adams RP, SiljakYakovlev S, Kharrat MB, Robert T. 2020. First Evidence for allotriploid Hybrids between Juniperus thurifera and J. sabina in A Sympatric Area in the French Alps. Ann Forest Sci 77: 93. https:// doi.org/10.1007/s13595-020-00969-7.

Farjon A, 2010. A Handbook of the World's Conifers (2 vols.). Brill Academic Publishers, Leiden, Boston, USA

Gauquelin T, Idrissi Hassani M, Lebreton P, 1988. Le Genévrier thurifère, Juniperus thurifera L. (Cupressacées): analyse biométrique et biochimique; propositions systématiques. Ecol. Mediterr 14: 31-42.

Gezer A, Yücedağ C, 2013. Forest Tree Seeds and Seedling Growth Techniques. $2^{\text {nd }}$ edn. Süleyman Demirel University Publications, Isparta, Turkey, No 56, $151 \mathrm{p}$.

Gülcü S, Gültekin HC, 2005a. Comparison of Seed Sources of Crimean Juniper (Juniperus excelsa Bieb.) in the Lakes District in Terms of Morphological Seedling Quality Criteria. KÜ Artvin Orman Fakültesi Dergisi 6 (1-2): 121-128.

Gülcü S, Gültekin HC, 2005b. Determination of Proper Sowing Techniques for Crimean Juniper (Juniperus excelsa Bieb.) and Small Fruited Juniper (Juniperus oxycedrus L.). SDÜ Orman Fakültesi Dergisi Seri: A, (1) 37-48.
Gülcü S, Gültekin HC, Çelik S, Eser Y, Gürlevik N, 2010. The Effects of Different Pot Length and Growing Media on Seedling Quality of Crimean juniper (Juniperus excelsa Bieb). Afr J Biotechnol 9 (14): 2101-2107.

Gülsoy AD, Gülsoy AM, Duman H, Kaya Z, 2012. Molecular Phylogeny of Juniperus Species in Turkey based on Noncoding trn Region of cpDNA. In: International Symposium on The Biology of Rare and Endemic Plant Species (BIORARE, 2012), 23-27 April, Muğla, Turkey.

Gültekin HC, 2007. Türkiye Ardıç (Juniperus L.) Türlerinin Ekolojisi ve Silvikültür Teknikleri. TMMOB Orman Mühendisleri Odası Yayın, Turkey, No: 27, pp. 16-19.

Gültekin HC, Çetin ME, Datumani A, Ateş M, Altınsoy S, Divrik A, Gültekin ÜG, Yiğci M, Divrik H, Sarılı Z, 2005. Göller Bölgesi Ardıç (Juniperus L.) Ağaçlandırma ve Yapay Gençleştirme Çalışmaları Hakkında Bazı Tespitler. Batı Akdeniz Ormancılık Araştırma Müdürlüğü Dergisi 6(1): 42-60.

Gültekin HC, Gülcü S, Gültekin ÜG, Divrik A, 2003. Boylu Ardıç (Juniperus excelsa Bieb.) Tohumlarına Ekimden Önce Uygulanabilecek Bazı Basit Sınıflandırma Yöntemlerinin Çimlenmeye Olan Etkilerinin Belirlenmesi Üzerine Araştrrmalar. Kafkas Üniversitesi Artvin Orman Fakültesi Dergisi 4(1-2): 11-119.

Gültekin HC, Gültekin ÜG, 2003. Boz Ardıç (Juniperus excelsa Bieb.) Tohumlarının Çimlenme Engellerinin Giderilmesi Üzerine Kül Kullanımının Etkisi. Bat Akdeniz Ormancılık Araştırma Müdürlüğü Dergisi Yayın No: 211, Sayı: 5, 29-42.

Gültekin HC, Gültekin ÜG, 2007. Türkiye'deki Ardıç (Juniperus L.) Türlerinin Silvikültür Teknikleri. Doğu Akdeniz Ormancllık Araştırma Müdürlüğü Dergisi 13: 69-111.

Haile G, Gebrehiwot K., Lemenih M., Bongers F, 2011. Time of Collection and Cutting Sizes Affect Vegetative Propagation of Boswellia papyrifera (Del.) Hochst through Leafless Branch Cuttings. Journal of Arid Environments 75(9): 873-877. https://doi. org/10.1016/i.jaridenv.2011.04.007.

Hojjati F, Zarre S, Assadi M, 2009. Isoenzyme Diversity and Cryptic Speciation in Juniperus excelsa (Cupressaceae) Complex in Iran. Biochem Syst Ecol 37: 193-200. https://doi.org/10.1016/i. bse.2009.03.002.

Hojjati F, Sereshti H, Hojjati M, 2019. Leaf Essential Oils and Their Application in Systematics of Juniperus excelsa Complex in Iran. Biochem Syst Ecol 84: 29-34. https://doi.org/10.1016/j. bse.2019.03.004

Houghton JT, Meiro Filho LG, Callander BA, Kattenburg A, Maskell K, 1996. Climate Change 1995. The Second Assessment Report of the IPCC. Cambridge University Press, Cambridge, UK.

IUCN, 2012. Turkey. Available online: http://iucn.org (25 September 2020).

Kapdan E, Sezgin M, Kahya M, 2019. The Use of Juniper (Juniperus L.) Species in the Treatment of Diseases Among People and in Modern Medicine. In: 2nd International Eurasian Conference on Biological and Chemical Sciences, 28-29 June 2019, Ankara, Turkey, p. 95.

Keskin S, 1989. Kokulu Ardıç (J. foetidissima Willd.) ve Boylu Ardıç (J. excelsa Bieb.) Çeliklerinin Köklendirilmesi Üzerine Çalışmalar. Ormancılık Araştırma Enstitüsü, Teknik Raporlar Serisi, Ankara, Turkey, No: 36-39: 37-48.

Khoshnevis M, Teimouri M, Sadegzadeh Hallaj MH, Matinizadeh M, Shircany A, 2019. The Effect of Canopy and Its Geographic Orientation on Seeds Germination and Survival of Juniperus excelsa Seedlings. Iranian Journal of Forest 11(3): 363-371.

Khoshoo T, 1959. Polyploidy in Gymnosperms. Evolution 13(1): 24-39. https://doi.org/10.2307/2405943.

Korshikov II, Nikolaeva AV, 2007. Genetic Control of Allozymes from the Juniper Tall (Juniperus excelsa Bieb.) of Crimea. Cytol Genetics 41: 209-212. https://doi.org/10.3103/S0095452707040032. 
Korshikov II, Nikolaeva AV, 2013. Genetic Variability of Juniper Tall (Juniperus excelsa Bieb.) in the Northern and Southern Limits of the Natural Distribution. Tsitol Genet 47: 33-41. https://doi. org/10.3103/S0095452713030043.

Lamb D, Gilmour D, 2003. Rehabilitation and Restoration of Degraded Forests. IUCN, Gland, Switzerland, and Cambridge, UK, and WWF, Gland, Switzerland.

Lamb D, Erskine PD, Parrotta JA, 2005. Restoration of Degraded Tropical Forest Landscapes. Science 310: 1628-1632. https://doi. org/10.1126/science.1111773.

MacLaren C, 2016. Climate Change Drives Decline of Juniperus seravschanica in Oman. J Arid Environ 128: 91-100. https://doi. org/10.1016/j.jaridenv.2016.02.001.

Mantang C, Dachang L, Turnbull TW, 2003. Rehabilitation of Degraded Forests to Improve the Livelihood of Poor Farmers: A Synthesis of Four Case Studies in South China. In: Dachang L (ed) Rehabilitation of degraded forests to improve livelihood of poor farmers in South China. Center for International Forestry Research, Bogor, Indonesia.

Marzo A, Herreros R, Zreik Ch, 2015. Guide of Good Restoration Practices for Mediterranean Habitats. Ecoplantmed, ENPI, CBCMED.

Mathaux C, Mandin J-P, Oberlin C, Edouard J-L, Gauquelin T, Guibal $F, 2016$. Ancient juniper trees growing on cliffs: toward a long Mediterranean tree-ring chronology. Dendrochronologia 37: 7988. https://doi.org/10.1016/j.dendro.2015.12.005.

Mazur M, Zielinska M, Boratynska K, Romo A, Salva-Catarineu MR, Marcysiak K, Boratynski A, 2018. Taxonomic and Geographic Differentiation of Juniperus phoenicea agg. based on Cone, Seed, and Needle Characteristics. System Biodivers 16(5): 469-482. https://doi.org/10.1080/14772000.2018.1439120.

MoE, 2009. Fourth National Report of LEBANON to the Convention on Biological Diversity. Lebanon. URL: https://www.cbd.int/doc/ world/lb/lb-nr-04-en.pdf

OGM, 2006. Action Plan for the Rehabilitation of Juniper forests (2006-2015). Ministry of Environmental and Forestry, General Directorate of Forestry, Ankara, Turkey.

OGM, 2019a. Ormancılık İstatistikleri. Available online: https://www. ogm.gov.tr/ekutuphane/Sayfalar/Istatistikler.aspx (27 September 2020).

OGM, 2019b. Türkiye, Dünya Ormancılığında Bir Illki Başararak Suni Yollardan Ardıç Fidanı Üretti. Available online: https://www. tarimorman.gov.tr/Haber/3894/Turkiye-Dunya-OrmanciligindaBir-Ilki-Basararak-Suni-Yollardan-Ardic-Fidani-Uretti September 2020).

OGM, 2020. Islah Tesisleri 2020. Available online: https://ortohum. ogm.gov.tr/Documents/Forms/Allltems.aspx?RootFolder=\%2fDoc uments\%2fislah\%5ftesisleri\&FolderCTID=0x012000B2E4 C64252896A4FBBF1D4DF0BB6AA58 (15 September 2020).

Orhan N, Akkol E, Ergun F, 2012. Evaluation of Antiinflammatory and Antinociceptive Effects of Some Juniperus Species Growing in Turkey. Turk J Biol 36(6): 719-726. https://doi.org/10.3906/biy1203-32.

Örtel E, Kavgacı A, Çalıkoğlu M, Türkkan M, Gültekin HC, Çobanoğlu A, 2020. Boylu Ardıın (Juniperus excelsa) Yapay Gençleştirilmesi. Ormancilık Araştırma Dergisi 7(1): 22-30. https://doi. org/10.17568/ogmoad.467372.

Otto SP, Whitton J, 2000. Polyploid Incidence and Evolution. Annu Rev Genet 34(1): 401-437. https://doi.org/10.1146/annurev. genet.34.1.401.

Pinna MS, Grillo, O, Mattana E, Cañadas EM, Bacchetta G, 2014. Interand Intraspecific Morphometric Variability in Juniperus L. Seeds (Cupressaceae). System Biodivers 12(2): 211-223. https://doi.org /10.1080/14772000.2014.904827.

Ramos-Palacios R, Orozco-Segovia A, Sánchez-Coronado ME, Barradas VL, 2012. Vegetative Propagation of Native Species Potentially Useful in the Restoration of Mexico City's Vegetation. Revista Mexicana de Biodiversidad 83(3): 809-816. https://doi. org/10.7550/rmb.21610.
Rawat YS, Everson CS, 2012. Ecological status and uses of juniper species in the cold desert environment of the Lahaul valley, Northwestern Himalaya, India. J Mt Sci-Eng/ 9(5): 676-686. https://doi. org/10.1007/s11629-012-2274-0.

Rincon A, Alvarez IF, Pera J, 2001. Inoculation of Containerized Pinus pinea L. Seedlings with Seven Ectomycorrhizal Fungi. Mycorrhiza 11: 265-271. https://doi.org/10.1007/s005720100127.

Romo A, Hidalgo O, Boratyński A, Sobierajska K, Jasińska AK, Vallès J, Garnatje T, 2013. Genome size and ploidy levels in highly fragmented habitats : the case of western Mediterranean Juniperus (Cupressaceae) with special emphasis on J. thurifera L. Tree Genet Genomes 9(2): 587-599. https://doi.org/10.1007/ s11295-012-0581-9.

Rozas V, De Soto L, Olano JM, 2009. Sex-specific, age depedent sensitivity of tree-ring growth to climate in the deciduous tree Juniperus thurifera. New Phytol 182: 687-697. doi: https://doi. org/10.1111/j.1469-8137.2009.02770.x.

Sadeghi-Aliabadi H, Emami A, Sadeghi B, Jafarian A, 2009. In vitro cytotoxicity of two subspecies of Juniperus excelsa on cancer cells. Iran J Basic Med Sci 11(4): 250- 253. https://doi.org/10.22038/ IJBMS.2009.5189.

Saeed S, Barozai MYK, Ahmed A, Tareen RB, Begum S, Ali GM, 2017. Impact of Ecological Diversity on Genetic and Phytochemical Variation in Juniperus excelsa from High Elevation Zones of Quetta Valley, Pakistan. Pak J Bot 49: 201-206.

Şahin $M$, Başaran S, Başaran MA, Okudan A, Alım E, Türkkan M, Serttaş A, Alagöz Z, 2014. Burdur Yöresindeki Erozyon Alanlarının Floristik Kompozisyonu ve Erozyon Önlemede Kullanılabilecek Bitki Türlerinin Belirlenmesi. II. Ulusal Akdeniz Orman ve Çevre Sempozyumu, 22-24 Ekim, Isparta, Turkey.

Sarangzai AM, Ahmed M, Ahmed A, Laghari SK, Jan SU, 2012. Juniper Forest of Balochistan: A Brief Review. FUUAST J Biol 2(1): 71-79.

Scott AD, Stenz NW, Ingvarsson PK, Baum DA, 2016. Whole Genome Duplication in Coast Redwood (Sequoia sempervirens) and Its Implications for Explaining the Rarity of Polyploidy in Conifers. New Phytol 211(1): 186-193. https://doi.org/10.1111/nph.13930.

Seim A, Omurova G, Azisov E, Musuraliev K, Aliev K, Tulyaganov T, Nikolyai L, Botman E, Helle G, Dorado Liñan I, Jivcov S, Linderholm HW, 2016. Climate Change Increases Drought Stress of Juniper Trees in the Mountains of Central Asia. PloS one 11(4): e0153888. https://doi.org/10.1371/journal.pone.0153888

Siljak-Yakovlev S, Pustahija F, Šolić E, Bogunić F, Muratović E, Bašić N, Catrice O, Brown S, 2010. Towards A Genome Size and Chromosome Number Database of Balkan Flora: C-values in 343 Taxa with Novel Values for 242. Advanced Science Letters 3(2): 190-213. https://doi.org/10.1166/asl.2010.1115.

Şirin G, Topay M, 2019. An Overview of the Use of Odorous Wood in Landscape Architecture Applications. Mimarlık Bilimleri ve Uygulamaları Dergisi 4(1): 90-96. https://doi.org/10.30785/ mbud.543191.

Soejono Budiharta S, Arisoesilaningsih E, 2013. Proposing Local Trees Diversity for Rehabilitation of Degraded Lowland Lands Surrounding Springs. Biodiversitas 14(1): 37-42. https://doi. org/10.13057/biodiv/d140106.

Soltis PS, Soltis DE, 2009. The Role of Hybridization in Plant Speciation. Annu Rev Plant Biol 60: 561-588. https://doi.org/10.1146/ annurev.arplant.043008.092039.

Sungur N, Bilir N, 2015. Determination of Success in Forest Rehabilitation of Isparta-Senirkent District. Süleyman Demirel Üniversitesi Fen Bilimleri Enstitüsü Dergisi 19(1): 107-111.

Tayalé A, Parisod C, 2013. Natural Pathways to Polyploidy in Plants and Consequences for Genome Reorganization. Cytogenet Genome Res 140(2-4): 79-96. https://doi.org/10.1159/000351318.

Te Beest M, Le Roux JJ, Richardson DM, Brysting AK, Suda J, Kubesová M, Pysek P, 2012. The More the Better? The Role of Polyploidy in Facilitating Plant Invasions. Ann Bot-London 109(1): 19-45. https://doi.org/10.1093/aob/mcr277.

Tektaş i, Türkoğlu N, Çavuşoğlu S, 2017. Effects of Auxin Doses on Rooting of Juniperus L. Progr Nutr 19: 130-136. https://doi. org/10.23751/pn.v19i1-S.5786.

https://www.seefor.eu 
Thang HC, 1987. Forest Management-Systems for Tropical High Forest, With Special Reference to Peninsular Malaysia. Forest Ecol Manag 21: 3-20. https://doi.org/10.1016/0378-1127(87)90069-7.

Thomas E, Jalonen R, Loo J, Boshier D, Gallo L, Cavers S, Bordács S, Smith P, Bozzano M, 2014. Genetic Considerations in Ecosystem Restoration Using Native Tree Species. Forest Ecol Manag 333: 6675. https://doi.org/10.1016/i.foreco.2014.07.015.

TOD, 2019. Türkiye Ormancılığı:2019, Türkiye Ormancılar Derneği, TOD Yayın no: 47, 164+20 s. Kuban Matbaacılık Yayıncılık, Ankara, Turkey.

TrAgLor, 2018. Türkiye ardıç yayılış alanları haritası. Available online: http://traglor.cu.edu.tr/objects/ objectFile/21 $12 \quad 2008 \quad 17 \quad 292$ ardic haritasi.jpg September 2020)

Van de Peer Y, Mizrachi E, Marchal K, 2017. The Evolutionary Significance of Polyploidy. Nat Rev Genet 18(7): 1-14. https://doi. org/10.1038/nrg.2017.26.

Vasilijevic B, Mitic-Culafic D, Djekic I, Markovic T, Knezevic-Vukcevic J, Tomasevic I, Velebit B, Nikolic B, 2019. Antibacterial Effect of Juniperus communis and Satureja montana Essential Oils against Listeria monocytogenes in Vitro and in Wine Marinated Beef. Food Control 100: 247-256. https://doi.org/10.1016/i. foodcont.2019.01.025.

Vrahnakis M, Nasiakou S, Soutsas K, 2017. Public perception on measures needed for the ecological restoration of Grecian juniper silvopastoral woodlands. Agroforest Syst https://doi.org/10.1007/ s10457-017-0163-9.

Weiss-Schneeweiss H, Emadzade K, Jang TS, Schneeweiss GM, 2013. Evolutionary Consequences, Constraints and Potential of Polyploidy in Plants. Cytogenet Genome Res 140: 137-150. https:// doi.org/10.1159/000351727.
Yücedağ C, 2008. Studies on Genetic Variation of Seed and Seedlings of Some Crimean juniper (Juniperus excelsa Bieb.) Populations in Turkey's Lakes District. PhD Thesis, University of Süleyman Demirel, Isparta, Turkey, $124 \mathrm{p}$.

Yücedağ C, Gezer A, Orhan H, 2010. The Genetic Variation in Crimean Juniper Populations from the Lakes District of Turkey. Rom Biotech Lett 15: 5487-5492.

Yücedağ C, Gailing O, 2013a. Genetic Variation and Differentiation in Juniperus excelsa M. Bieb. Populations in Turkey. Trees 27(3): 547554. https://doi.org/10.1007/s00468-012-0807-3.

Yücedağ C, Gailing O, 2013b. Differences among Juniperus excelsa Populations as Revealed at Morphological Traits. Dendrobiology 70: 73-81. https://doi.org/10.12657/denbio.070.007.

Yücedağ C, Özel HB, 2017. The Genetic Variation of Seven Natural Crimean Juniper (Juniperus excelsa Bieb. M.) Populations and Its Growing Environmental Conditions in Turkey. Fresen Environ Bull 27: 1210-1213.

Yücedağ C, Çiçek N, Gailing O, 2021. Local Adaptation at a Small Geographic Scale Observed in Juniperus excelsa Populations in Southern Turkey. (Submitted).

Zahawi RA, Holl KD, 2014. Evaluation of Different Tree Propagation Methods in Ecological Restoration in the Neotropics. In: Bozzano M, Jalonen R, Thomas E, Boshier D, Gallo L, Cavers S, Bordacs S, Smith P, Loo J (eds) Genetic Considerations in Ecosystem Restoration Using Native Tree Species. FAO, Rome, Italy, Chapter 8, pp. 85-96.

Zivic N, Milosevic S, Dekic V, Dekic B, Ristic N, Ristic M, Sretic L, 2019. Phytochemical and Antioxidant Screening of Some Extracts of Juniperus communis L. and Juniperus oxycedrus L. Czech J Food Sci 37(5): 351-358. https://doi.org/10.17221/28/2019-CJFS. 